\title{
SOUTH AFriCAN EXPORTER PERFORMANCE: NEW RESEARCH INTO FIRM-SPECIFIC AND MARKET CHARACTERISTICS
}

\author{
Christopher May \\ Department of Management, University of the Western Cape \\ Charles O'Neill \\ School of Management, University of KwaZulu-Natal
}

\begin{abstract}
The export marketing performance of any firm is influenced by a multitude of different factors. Given the multi-faceted nature of the export market, this research study investigated specific factors such as how firm-specific characteristics, product characteristics, market characteristics and export marketing strategies impact on the export marketing performance of South African manufacturing firms. Some of the findings of this research study indicated that firm size, investment commitment and careful planning, as firm-specific characteristics, had a significant influence on export marketing performance. The relationship between export experience and export marketing performance was insignificant. The degree of pricing adaptation and product adaptation had a significant effect on export marketing performance, while this was not the case with respect to the degree of promotion adaptation and distributor support.

JEL F14, M31, P45
\end{abstract}

\section{1 Introduction}

Trade among countries has rapidly increased over the past ten years and interdependence among countries has increased phenomenally. The competitive landscape has changed as a result of the emergence of a more open world economy and technological advances, especially in transportation and communication. In the context of the internationalisation of firms and the greater integration of markets, South African firms will be facing more competition from foreign firms than before. It is therefore essential for South African firms to identify ways in which to harness their competitive advantages, as well as to reduce their competitive disadvantages.

The objective of this research study was to empirically investigate and identify the most important factors that impact on the export marketing performance of South African manufacturing firms. The literature review provides a concise overview of the influence of firm-specific characteristics, product characteristics, market characteristics and export marketing strategies on the export marketing performance of firms. Furthermore, the debate of whether to standardise or adapt export marketing strategies is also reviewed. The review of the literature is followed by the research methodology section that explains the theoretical and conceptual basis of the empirical study. Finally, the findings, recommendations, limitations of the study, directions for future research and the conclusion are presented.

\section{2}

\section{A brief review of the literature}

Firm-specific and entrepreneurial factors are the internal forces that influence a firm's decision to internationalise and are also important determinants of the firm's international marketing strategy that would ultimately affect its performance in international markets (Cicic, 
Patterson \& Shoham, 2002: 1104-1107; Thirkell \& Dau, 1998: 813-821; Cavusgil \& Zou, 1994: 1-5). According to Morgan (1997: 71) the stimuli to internationalise can be classified as being either proactive or reactive in nature. Proactive stimuli originate from a firm's unique internal competencies and are known as pull factors. Reactive stimuli on the other hand, explain the firm's international engagement as a response to environmental pressures.

While export marketing performance, the dependent variable, may be influenced by a multitude of factors, namely, the independent variables, it was decided within the length confines of this article to focus on the four broad groups of variables that mainly influence export marketing performance as identified by O'Cass and Julian (2003a:56). These four groups of variables are: firm-specific characteristics, product characteristics, market characteristics and export marketing strategies.

However, there is no common agreement on how to operationalise export marketing performance as the dependent variable. Previous research studies have used different variables to operationalise export marketing performance, hence the inconsistencies in findings. For example, Shoham (2002: 116) used a composite or summated scale of four variables to operationalise export marketing performance, namely, international sales, international profits and changes in each. Das (1994: 24), on the other hand, measured success of exporting in two ways, namely, percentage of exports to sales (export intensity) and growth in export volume during the past five years.

A number of variables and marketing strategies can impact on the export marketing performance of firms. For example, firm-specific and product characteristics, as independent variables, can have a major impact on the export marketing performance of firms. Firmspecific characteristics such as size of the firm, export/international experience, years in business, managers' attitude toward exporting, commitment and leadership were some of the characteristics identified as being important for a firm to succeed in export markets (Das, 1994: 33). The age of a product, the uniqueness of a product, innovative technological products and patents are examples of product characteristics that can influence export marketing performance (Cavusgil \& Zou, 1994: 9). Just as there are advantages to internationalisation, there are also disincentives or barriers to a firm's success in export markets. Market characteristics such as access to distributors, import control, government legislation, exchange rate fluctuations, cultural differences, language differences and unfamiliar business practices can negatively impact on export marketing performance.

Many researchers have endeavoured to determine how either standardisation or adaptation of international marketing mix strategies affect the export marketing performance of a firm (Albaum \& Tse, 2001: 59; Samiee \& Roth, 1992: 1; Melewar \& Saunders, 1999: 583; Schuh, 2000: 133). In the studies mentioned, researchers used different units of analyses, analysed different products and industries and surveyed varying firm sizes. Consequently, conflicting results concerning the relationship between adaptation of export marketing strategies and firm performance, and the relationship between standardisation of export marketing strategies and firm performance were found (Shoham, 1995: 109). Chung (2005: 1345) notes, that despite forty years of development in the literature with regard to the standardisation and adaptation of marketing strategies, many of the theories that have been developed still need to be established as conclusive.

Product and promotion are elements of the marketing mix that are more frequently adapted than the other elements of the marketing mix (Cavusgil, Zou \& Naidu, 1993: 485). Product adaptations are normally the response of a firm to the legal and technical requirements of a particular country. According to Schuh (2000: 142), adaptations or adjustments occur mainly among the non-core elements of the product mix, for example, labelling content, package design, names of consumer products and product instructions when translated. Labelling and label symbols exhibit the highest levels of adaptation (Leonidou, 1996: 63). Factors such as differences in consumer needs, buying behaviour, cultural differences and variations in ability to afford would favour a strategy of marketing adaptation 
(Chee \& Harris, 1998: 375). High costs of adaptation, scale economies in production and marketing, and the convergence of markets with regard to similar tastes would favour the standardisation of products.

With regard to promotion strategies, the controversy around using standardised or localised advertising campaigns has not been settled yet (Kanso \& Nelson, 2002: 79; Harris, 1996: 5; Papavassiliou \& Stathakopoulos, 1997: 504; Agrawal, 1995: 26). Elinder (1965) was the first to take up the debate in the 1960s of whether to standardise or adapt promotion strategies. The proponents of standardisation argue that because of faster communication there is a convergence of art, media activity, living conditions and cultures. Because of this convergence, advertising should be standardised (Kanso \& Nelson, 2002: 79).

Many scholars acknowledge that selecting channels of distribution is a complex and difficult task for a number of reasons (Rialp, Axinn \& Thach, 2002: 133; Vandersluis, 1999: 13; Griffith \& Ryans, 1995: 52). The following are some of the questions to be considered when deciding which distribution strategy to use: First, what extent of control does the firm want to exercise over its channel members? Second, how selective should the distribution channel be? Third, what types of channel members are to be selected? And finally, how many channels should be established for a given product? The lack of information regarding distribution alternatives is another problem cited that inhibits the improvement in the efficiency and effectiveness of marketing programmes (Richey \& Myers, 2001: 335). Moreover, Griffith and Ryans (1995: 52) argue that it is because of the complexities of international channels that research in this area has been very limited.

Notwithstanding the fact that pricing is complex in domestic markets, it is even more difficult in international markets due to factors such as multiple currencies, the instability of economies of foreign countries, trade barriers, additional cost considerations and longer distribution channels (Raymond, Tanner \& Kim, 2001: 20; Cavusgil, 1996: 67; Samli \& Jacobs, 1993/1994: 29). The market competitive structure, market pricing structure, distribution structure and consumer behaviour are viewed by Marsh (2000: 202) as critical factors at the micro level that influence pricing. Macro level factors include factors such as economic conditions, government legislation and social factors.

The literature review focused on the four most important groups of variables that can influence export marketing performance as identified by the research of O'Cass and Julian (2003a; 56), namely, firm-specific characteristics, product characteristics, market characteristics and export marketing strategies. The empirical research conducted to determine the impact of these variables on export marketing performance is dealt with in the next section.

3

\section{Methodology}

A self-administered mail survey was conducted to determine the impact of selected independent variables on the export marketing performance of South African manufacturing firms. The development of the questionnaire was mainly based on Cavusgil and Zou's framework (1994). Selection of this conceptual framework was influenced by the views of leading researchers in this field of study (Julian, 2003: 214; Styles, 1998: 13). The objective was also to select previously validated scales to obtain valid and reliable measures of the variables (O'Cass \& Julian, 2003b: 374). The questionnaire consisted of only closed-ended and 5-point Likert scale questions. The questionnaire was pre-tested, and content and face validity were established by consulting ten exporters and eleven academics at two universities. A number of changes were suggested and implemented prior to distribution.

A sample size of 1153 (50 per cent) of the sample frame of 2305 was randomly selected. The sample frame was the Database of Manufacturing Exporters of the Bureau of Market Research at the University of South Africa. A cover letter, the questionnaire and a pre-paid reply envelope were mailed to the respondents. A total number of a 173 firms responded, 45.5 per cent (77) were consumer firms and 55.5 per cent (96) were industrial firms. A response rate of 17 per cent was attained. 
Non-response bias was determined by following the guidelines of Armstrong and Overton (1977: 396). Mail surveys have been criticised for non-response bias and as such Armstrong and Overton (1977: 396) have highlighted three methods of estimation, namely, comparisons with known values for the population, subjective estimates, and extrapolation. The extrapolation method was used to determine potential non-response bias. The extrapolation method entails the comparison of the data of late respondents with that of early respondents, and it is assumed that late respondents have similar characteristics to that of non-respondents.

Early respondents were compared with late respondents with respect to the following variables; consecutive years in export, firm by class size, international sales growth for the last financial year, total international sales for the last financial year, total domestic sales for the last financial year, satisfaction with international sales and satisfaction with international profits. Independent sample t-tests were used to determine whether significant differences existed between early and late respondents (Lages \& Lages, 2004: 45; Morgan, Kaleka \& Katsikeas, 2004: 95; O'Cass \& Julian, 2003b: 375; Morgan \& Katsikeas, 1998: 168). Early respondents were considered as the first 70 per cent of the returned questionnaires and late respondents as the last 30 per cent. Both the Levene's test for equality of variances and the 2 -tailed results had values of more than .05 . The results therefore indicated that non-response bias was not a serious concern and addressed the issue of sample representativeness.

Exploratory factor analysis and coefficient alpha were used to purify the construct measures (Churchill, 1979: 66). Table 1 presents the factors extracted for each of the independent variables through the use of factor analysis. The factors that were selected were subjected to reliability analysis. For example, firm-specific characteristics loaded on two components and these factors were renamed as 'firm competencies' and 'government support'. The factor 'firm competencies' included that: the firm has unique management competencies, the firm has international marketing skills, the firm has unique product competitive advantages, the firm has extensive international market knowledge, the firm provides adequate resources and the firm has production competencies. Coefficient alpha was used to test the reliability of the firm competency construct, made up of the six aforementioned competencies. It had a high reliability value of .760 (see Table 2 ).

The purified measurement model (Table 2) presents a summary of the constructs that were included for further analysis. Apart from the composite scales developed from the factor analysis exercise, a number of single item scales were included. These single item scales were identified in the literature review as important variables influencing export marketing performance. They were: consecutive years in export, firm by class size, investment commitment, competitive intensity, committed management, and whether management engages in careful planning. Market characteristics loaded on only one component and all the items were included to develop the market characteristics construct. Export marketing strategies loaded on four factors. Only one of the product characteristics items, namely, that a firm has unique product competitive advantages, loaded onto the firm-specific construct. The other product characteristics were eliminated through the factor analysis exercise. 


\section{Table 1}

Summary of the extracted factors of the independent factors

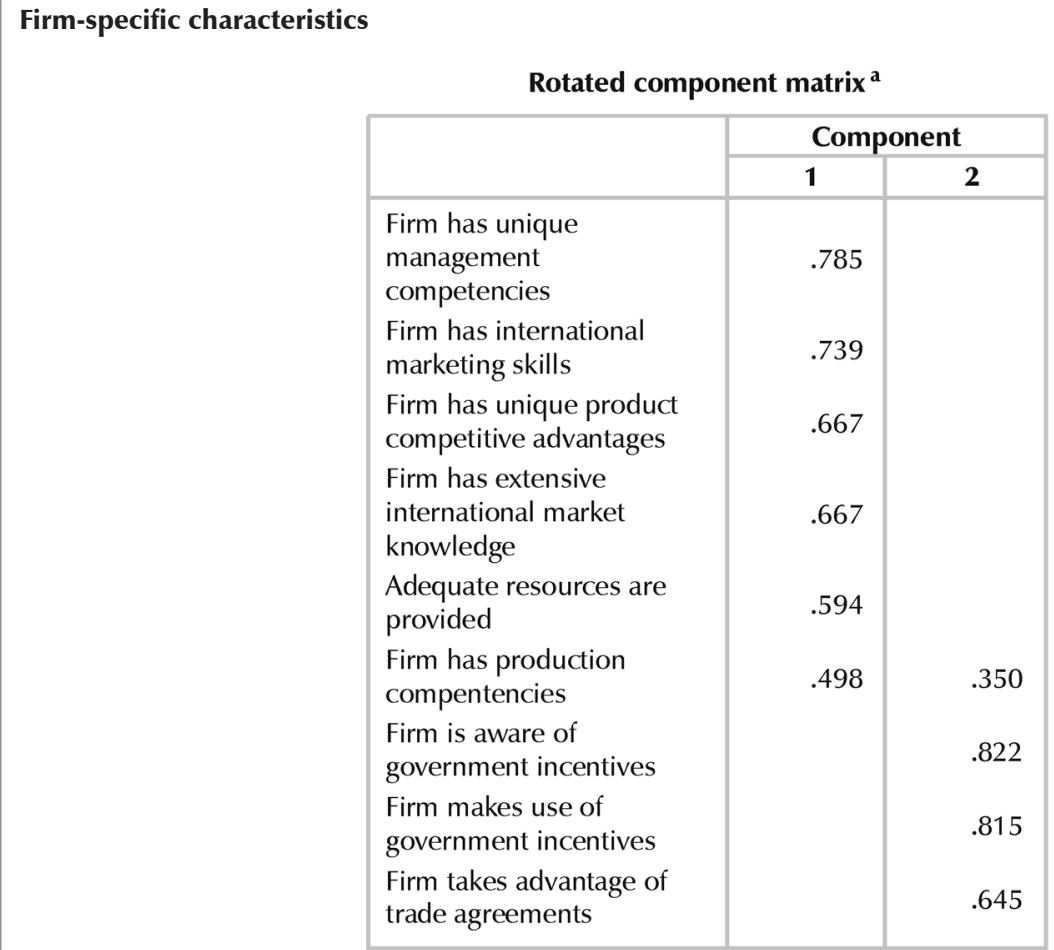

Extraction method: Principal component analysis Rotation method: Varimax with Kaiser normalisation

a Rotation converged in 3 iterations

\section{Market characteristics}

\section{Component matrix ${ }^{a}$}

\begin{tabular}{|l|c|c|}
\hline \multirow{2}{*}{} & \multicolumn{2}{|c|}{ Component } \\
\cline { 2 - 3 } & $\mathbf{1}$ & $\mathbf{2}$ \\
\hline Exchange rate risk & .309 & -.149 \\
Foreign tariffs & .631 & -.457 \\
Import controls & .714 & -.457 \\
Foreign legislation & .664 & -.381 \\
requirements & .534 & .620 \\
Language barriers & .680 & .396 \\
Channel accessibility & .699 & .448 \\
Cultural differences & \\
\hline
\end{tabular}

Extraction method: Principal component analysis

a 2 components extracted 
Table 1

Continued

\section{Export marketing strategies}

Rotated component matrix ${ }^{\mathbf{a}}$

\begin{tabular}{|c|c|c|c|c|}
\hline & \multicolumn{4}{|c|}{ Component } \\
\hline & 1 & 2 & 3 & 4 \\
\hline $\begin{array}{l}\text { Distributor and subsidiary } \\
\text { support }\end{array}$ & .883 & & & \\
\hline $\begin{array}{l}\text { Spend substantial } \\
\text { amounts on overall } \\
\text { promotion }\end{array}$ & .849 & & & \\
\hline Build brand awareness & .779 & & & \\
\hline $\begin{array}{l}\text { Degree of promotional } \\
\text { adaptation }\end{array}$ & .584 & .502 & & \\
\hline $\begin{array}{l}\text { Mainly uses sales } \\
\text { promotion to final } \\
\text { customers }\end{array}$ & .563 & & & \\
\hline $\begin{array}{l}\text { Degree of subsequent } \\
\text { adaptation }\end{array}$ & & .831 & & \\
\hline $\begin{array}{l}\text { Degree of initial product } \\
\text { adaptation }\end{array}$ & & .774 & & \\
\hline $\begin{array}{l}\text { Degree of adaptation of } \\
\text { positioning }\end{array}$ & & .658 & & \\
\hline $\begin{array}{l}\text { Degree of pricing } \\
\text { adaptation }\end{array}$ & & .625 & & \\
\hline $\begin{array}{l}\text { Degree of packaging } \\
\text { adaptation }\end{array}$ & & .461 & & \\
\hline Direct sales to end users & & & -.744 & \\
\hline $\begin{array}{l}\text { Use high quality } \\
\text { channels }\end{array}$ & & & .688 & \\
\hline $\begin{array}{l}\text { Mainly uses sales } \\
\text { Promotion to trade }\end{array}$ & & & .545 & \\
\hline Use short channels & & & .514 & \\
\hline $\begin{array}{l}\text { Participate in trade } \\
\text { shows }\end{array}$ & .386 & & .429 & \\
\hline $\begin{array}{l}\text { Have high customer } \\
\text { contact }\end{array}$ & & & & .690 \\
\hline High levels of control & & & & .639 \\
\hline $\begin{array}{l}\text { Use well trained } \\
\text { salespeople }\end{array}$ & & & & .589 \\
\hline Regular overseas trips & & & & .564 \\
\hline Low prices & & & & -.402 \\
\hline
\end{tabular}

Extraction method: Principal component analysis

Rotation method: Varimax with Kaiser normalisation

a Rotation converged in 5 iterations 
Table 2

Purified measurement model

\begin{tabular}{|c|c|c|c|}
\hline Factors included & $\begin{array}{l}\text { KMO } \\
\text { measure }\end{array}$ & $\begin{array}{l}\text { Coefficient } \\
\text { alpha }\end{array}$ & $\begin{array}{l}\text { Corrected } \\
\text { item-total } \\
\text { correlation }\end{array}$ \\
\hline Export marketing performance & 690 & .708 & \\
\hline Sales growth Y1 & & & .423 \\
\hline Sales growth Y2 & & & .503 \\
\hline Sales growth Y3 & & & .548 \\
\hline Sales growth Y4 & & & .582 \\
\hline Sales growth last financial year Y5 & & & .386 \\
\hline Profitability Y1 & & & .240 \\
\hline Profitability Y2 & & & .288 \\
\hline Profitability Y3 & & & .385 \\
\hline Profitability Y4 & & & .444 \\
\hline Profitability last financial year Y5 & & & .293 \\
\hline Total export sales for LFY - Y5 & & & .162 \\
\hline Satisfaction with international sales & & & .220 \\
\hline Satisfaction with international profits & & & .160 \\
\hline Firm competencies & .718 & .760 & \\
\hline $\begin{array}{l}\text { Firm has unique management } \\
\text { competencies }\end{array}$ & & & .437 \\
\hline Adequate resources are provided & & & .450 \\
\hline $\begin{array}{l}\text { Firm has extensive international } \\
\text { market knowledge }\end{array}$ & & & .537 \\
\hline $\begin{array}{l}\text { Firm has unique management } \\
\text { competencies }\end{array}$ & & & .579 \\
\hline $\begin{array}{l}\text { Firm has international marketing } \\
\text { skills }\end{array}$ & & & .580 \\
\hline Firm has production competencies & & & .436 \\
\hline Export market characteristics & .721 & .731 & \\
\hline Exchange rate risk & & & .191 \\
\hline Foreign tariffs & & & .453 \\
\hline Import controls & & & .504 \\
\hline Foreign legislation requirements & & & .448 \\
\hline Channel accessibility & & & .489 \\
\hline Language barriers & & & .435 \\
\hline Cultural differences & & & .599 \\
\hline
\end{tabular}


Table 2

Continued

\begin{tabular}{|l|c|c|c|}
\hline \multicolumn{1}{|c|}{ Items } & $\begin{array}{c}\text { KMO } \\
\text { measure }\end{array}$ & $\begin{array}{c}\text { Coefficient } \\
\text { alpha }\end{array}$ & $\begin{array}{c}\text { Corrected } \\
\text { item-total } \\
\text { correlation }\end{array}$ \\
\hline $\begin{array}{l}\text { Promotion adaptation } \\
\text { Spends substantial amounts on }\end{array}$ & .712 & .608 \\
overall promotion & & .513 \\
Builds brand awareness & & .519 \\
$\quad$ Degree of promotional adaptation & & .820 & .386 \\
$\quad$ Mainly uses sales promotion to & & .695 \\
$\quad$ final customers & & .695 \\
Product adaptation & & .582 & .375 \\
$\quad$ Degree of initial product adaptation & & & .346 \\
$\quad$ Degree of subsequent adaptation & & & .391 \\
Distribution support & & & .334 \\
$\quad$ Regular overseas trips & & 1.00 \\
High levels of control & & N.A. & 1.00 \\
$\quad$ Has high customer contact & N.A. & 1.00 \\
$\quad$ Uses well trained salespeople & N.A. & 1.00 \\
Pricing adaptation & N.A. & 1.00 \\
Export experience & N.A. & 1.00 \\
Firm size & N.A. & 1.00 \\
Investment commitment & N.A. & \\
Competitive intensity & & \\
Committed management & & & \\
Management engages in careful planning & & & \\
\hline
\end{tabular}

Three factors under export marketing strategies were identified and included for further analysis, namely, factors 1, 2 and 4 (see Table 1). Factor 3 was not taken into account because many different items loaded on this factor. Factors 1, 2 and 4 were renamed as promotion adaptation, product adaptation and distributor support respectively. The variables under pricing strategies were not included in the factor analysis exercise as the responses were considered to be inadequate. For example, when respondents were asked whether their firms set high or low prices, they invariably indicated no, and said they were setting competitive prices. By setting competitive prices one can only assume that the pricing for products is adapted.

The Kaiser-Meyer-Olkin (KMO) measure of sampling adequacy, the coefficient alpha and the corrected item-total correlations are also provided in Table 2. All the KMO values were greater than .6 (the acceptable level for sampling adequacy) for export marketing performance, firm-specific characteristics and export market characteristics. The KMO value for international marketing strategies was .669. The coefficient alpha values for all composite scales were greater than .70, except for the distribution support scale which was .582. However, the distribution support scale has been included because it was viewed as an important variable influencing export marketing performance. Government support was not included for further analyses, as it was not considered important in determining a firm's export marketing performance. Other variables, for example, such as adaptation to positioning and packaging were eliminated from further analysis through the factor analysis exercise. 
The hypothesis developed was based on the literature review conducted and after factor and reliability analyses had been performed. It is therefore hypothesised that export marketing performance is enhanced when the:

a. degree of product adaptation increases

b. degree of promotion adaptation increases

c. degree of distributor/subsidiary support increases

d. degree of pricing adaptation increases

e. firm's export marketing experience increases

f. firm size increases

g. investment commitment increases

h. competitive intensity decreases

i. management's commitment to exporting increases

j. management engages in more careful planning

k. firm competencies increase

1. export market barriers decrease (export market characteristics)

Sales growth and profitability for the last five years, actual sales for last financial year (Y5) and satisfaction with regard to international sales and profits were the objective and subjective measures used in this research study to operationalise export marketing performance (see Table 2).

\section{4 \\ Findings}

Multiple regression analysis was conducted and Table 3 provides the coefficient table results with regard to the significant relationships between export marketing performance and the specified independent variables. The $\mathrm{R} 2$ for the regression equation was .181 (the adjusted $\mathrm{R} 2$ was .119 and the $\mathrm{F}$ value was significant at the .001 level) which indicates how much of the variance of the dependent variable is explained by the model. With regard to the $\mathrm{R} 2$ value, Sudman and Blair (1998: 517) state that there is no rule as to what fraction of the variance needs to be explained to conclude that the relationship is strong or very strong. According to them, many researchers would consider an R2 of .30 or larger to be moderately strong. The $\mathrm{R} 2$ for the regression equation in this study was acceptable and statistically significant $-\mathrm{p}<.001$ (Cavusgil, Zou \& Naidu, 1993: 494). Multicollinearity was not a problem, as all the values in the tolerance column of the coefficients table were quite high (see Table 3). Should these values have been near zero then it would have been an indication of multicollinearity (Pallant, 2003: 143).

Firm size, degree of investment commitment, competitive intensity, management engagement in careful planning, degree of product adaptation and degree of pricing adaptation had a significant effect on export marketing performance. Competitive intensity had a significantly negative effect on export marketing performance, being that the greater the intensity of competition the lower the export marketing performance of a firm.

Table 3

Multiple regression analysis results

\begin{tabular}{|c|c|c|c|c|}
\hline \multirow[b]{2}{*}{ Model } & \multirow[b]{2}{*}{$T$} & \multirow[b]{2}{*}{ Sig. } & \multicolumn{2}{|c|}{ Collinearity statistics } \\
\hline & & & Tolerance & VIF \\
\hline Degree of product adaptation & -2.055 & $.042 *$ & .824 & 1.214 \\
\hline Degree of promotion adaptation & 1.418 & .158 & .834 & 1.198 \\
\hline Distributor support & -.021 & .984 & .670 & 1.492 \\
\hline Degree of pricing adaptation & 2.241 & $.026^{*}$ & .685 & 1.504 \\
\hline
\end{tabular}




\begin{tabular}{|l|c|c|c|c|}
\hline Export experience & 1.269 & .206 & .945 & 1.058 \\
\hline Firm size & 1.893 & $.060 \#$ & .835 & 1.198 \\
\hline Investment commitment & 2.046 & $.041^{*}$ & .959 & 1.043 \\
\hline Competitive intensity & -2.336 & $.021^{*}$ & .765 & 1.308 \\
\hline Management is committed & -.010 & .992 & .687 & 1.455 \\
\hline Mngt engages in careful planning & 2.138 & $.034^{*}$ & .620 & 1.614 \\
\hline Firm competencies & .559 & .577 & .497 & 2.013 \\
\hline Export market characteristics & .627 & .531 & .838 & 1.193 \\
\hline
\end{tabular}

Dependent variable: Export marketing performance

$$
\begin{aligned}
& \# p<.10 \\
& { }^{*} p<.05 \\
& { }^{* *} p<.001
\end{aligned}
$$

Product adaptation had a negative relationship with export marketing performance. One can only assume that the greater the product adaptation the greater the costs incurred to bring about product adaptation. One would have expected that the greater the degree of product adaptation, the greater the export marketing performance. However, Cavusgil and Zou (1994: 15) found a significant positive relationship in their study with regard to this relationship. They argued that export marketing performance can be substantially enhanced through product adaptation. Shoham (2002: 116) also suggests that firms should pursue a high degree of product adaptation as it will improve export marketing performance. Cavusgil and Zou (1994: 15) also state that a high degree of product adaptation is found where the firm is either internationally competent, the product is unique or culture specific, the industry is less technology intensive or the export market is competitive.

A non-significant relationship was found between the degree of promotion adaptation and export marketing performance. However, Cavusgil and Zou (1994: 15) found a significant but negative relationship. According to the authors, this was an unexpected finding and they argued that adaptation to promotion should be done after due consideration of costs and benefits. Previous research studies have found that adapting international promotion strategies can affect performance (Cavusgil \& Zou, 1994: 15). Firms tend to adapt their international promotion strategy when the product has some unique features or is not a technology-intensive product. Firms view relationships with foreign partners as key to the success of export marketing.

Cavusgil, Zou and Naidu (1993: 499) found that a greater adaptation of product and promotion is necessary for consumer products than for industrial products. However, in this research study, there were no significant differences between consumer and industrial firms with regard to the degree of adaptation of international marketing mix strategies. Furthermore, it can be assumed that the more a firm adapts its pricing to be competitive, the more this impacts positively on the firm's performance. Firm experience, firm competencies, commitment of management, export market characteristics, the degree of promotion adaptation and distributor support had no significant effects on export marketing performance.

The findings of this research study indicated that firm size, investment commitment and management engagement in careful planning as firm-specific characteristics had a significant influence on export marketing performance. Notably, O'Cass and Julian (2003a: 67), Baldauf, Cravens and Wagner (2000: 61) and Dean, Mengüç and Myers (2000: 471) also found that firm size has a significant effect on export marketing performance. Calof (1994: 384) found that the propensity for South African firms to export tends to increase as a firm grows in size 
but he did not indicate the relationship between firm size and export marketing performance.

In a South African study conducted by Rankin (2002: 3) in the Greater Johannesburg Metropolitan area, it was found that larger firms are more likely to export, but once a firm of any size exports, it seems that the size of the firm does not subsequently matter. Findings on firm size are still a controversial issue, as studies in the past have used different measures to determine size, such as, number of people employed, total foreign sales, export intensity and foreign sales growth.

O'Cass and Julian (2003a: 57), O'Cass and Julian (2003b: 367) and Cavusgil and Zou (1994:5) also identified that firm characteristics such as sustainable competitive advantages, channel support, size advantages, international experience, extent of international involvement, resources available, culture specificity, strength of patent and product uniqueness impact positively on export marketing performance.

The finding on the relationship between export experience and export marketing performance was insignificant. This is in contradiction with other studies, for example Das (1994: 27) highlighted the fact that foreign experience was related to success in exporting. According to him, while there were contradictory findings in the past, he found that managers in firmspecifics with higher export intensity had higher foreign experience. Cavusgil and Zou (1994: 15) referred to international competence as another firm-specific characteristic that significantly enhances export marketing performance. International competence is obviously also influenced through international experience gained by managers.

Investment commitment (as a surrogate for market entry mode), as a firm-specific characteristic was introduced in the model to determine whether or not mode of current entry has an influence on export marketing performance. The theoretical argument for this is that different entry modes have varying levels of control, commitment, involvement and risks (Albaum, Duerr \& Strandskov, 2005: 252). The finding of this research was that the greater the investment commitment, the greater the export marketing performance. The firm-specific characteristic of management engagement in careful planning had a significant effect on export marketing performance. The research studies of Shoham (1999: 41) and Shoham and Kropp (1998: 120) had similar findings.

\section{5}

\section{Recommendations}

In terms of the export marketing strategies of firms, it is recommended that pricing should be adapted to increase profitability, given the interplay of internal and external determinants with regard to export marketing mix strategy and export marketing performance. Given the negative relationship between the degree of product adaptation and export marketing performance, it is recommended that more care should be taken in decision making when product adaptations are considered. All costs and benefits in decision-making should be evaluated. The negative correlation may be explained by the phenomenon that increases in costs with regard to product adaptations do not necessarily have a positive impact on export marketing performance. Although there were no significant relationships found between promotion adaptation and export marketing performance, product and promotion adaptation decisions are still key factors in attaining export marketing performance. Many other studies have reported positive relationships between these two variables and export marketing performance (Zou \& Stan, 1998: 348).

Given the findings on firm-specific characteristics, it is recommended that South African firms need to review their market entry strategies to enhance export marketing performance. Firms should also implement sound planning processes that would aid the planning of export activities. Furthermore, firms should invest more resources to support foreign trading activities. Recruitment of marketing people with experience in foreign trade and exporting is very important. People with more foreign/ international experience should be used to develop the competence of other staff members in the organisation for future sustainability. Staff going on more international visits can also improve the knowledge base of the firm. 
The nature and characteristics of the export market can either serve as a barrier to or a driving force that facilitates internationalisation. These barriers and/or driving forces can also influence the nature of the international marketing mix strategies that are employed by firms. The barriers and/or driving forces can have both direct and indirect effects on export marketing performance. The competitive intensity of the export markets had a significant relationship with export marketing performance. Furthermore, the competitive intensity had the most significant relationship compared to all the other independent variables and as the relationship was negative, this means that the export marketing performances of firms is negatively affected by increased competitive activity.

South African manufacturing firms should especially analyse the competitive nature of the export market to determine to what extent their marketing mix strategies need to be adapted. Given the significant findings with regard to export market characteristics, firms need to look at ways to overcome these differences. Such strategies could include improving foreign language skills, employing people from the foreign market, arranging more foreign visits for employees, developing business contacts and networking, improving relationships with foreign intermediaries, developing strategic alliances with foreign firms, and investigating how promotion strategies in foreign markets could be improved.

Awareness of export market characteristics is imperative. Legal and cultural differences between domestic and export markets should be identified. These differences determine to what extent products will need to be adapted. If it is costly to adapt a particular product to suit an export market, that firm should then seriously consider if it is worthwhile entering that particular export market.

\section{6}

\section{Limitations of the study and directions for future research}

A major challenge in conducting research is that of obtaining reliable and objective information. Many firms were not prepared to provide exact figures on profits and sales, as these were viewed as confidential or sensitive. The sales and profitability questions were retrospective in nature, as respondents had to provide information over a five-year period, and as Cavusgil and Zou (1994: 17) and Dean, Mengüç and Myers (2000: 474) point out, it is problematic to rely on a manager's retrospective perceptions. The factor analysis uncovered that the responses to these questions did not load on the same constructs. However, all the objective and subjective questions on sales and profitability were included in one composite scale.

The research study was largely cross-sectional and the findings of the regression analysis were based on manufacturing firms of South Africa in general, and were not sector specific. There is therefore scope to investigate the specific export marketing performance of firms in different sectors and the variables that impact on these firms' performances. Similarly, the export marketing strategies of firms in different countries and the strategies employed by industrial and consumer firms could also be investigated.

Katsikeas, Leonidou and Morgan (2000: 507) refer to the lack of longitudinal studies in export marketing and this, in their opinion, is detrimental to dynamic model building and the determination of the long-term stability and functional relationships between export marketing performance and the variables that affect it. Although the study indicated the impact of the independent variables on export marketing performance, no distinction was made between high performing (more successful) firms and low performing (less successful) firms. The findings would have been of more value if one could have determined which variables were significantly affecting export marketing performance with respect to both the more and less successful firms in export markets.

\section{7 \\ Conclusion}

Given the increasingly competitive nature of international markets, it has become more important for South African firms to identify the success factors in their particular industries that would contribute to greater export marketing 
performance. While this study provided a number of insights, it should be viewed in terms of the limitations discussed. However, while the research study can be classified as exploratory in nature, it demonstrated strong relationships between firm-specific characteristics, export market characteristics, export marketing mix strategies and export marketing performance. These relationships will need to be monitored and continue to be researched, as their relevance will change over time. Changes in market structures, the development of the economies of countries, trends with regard to homogenisation of the world, further reduction of trade barriers, and developments in communication, transportation and technology are some of the factors that would influence the importance of the variables that will have an impact on export marketing performance.

\section{References}

1 AGRAWAL, H. (1995) "Review of a 40-year debate in international advertising”, International Marketing Review, 12(1): 26-48.

2 ALBAUM, G.; DUERR, E. \& STRANDSKOV, J. (2005) International Marketing and Export Management ( $5^{\text {th }}$ ed.) Prentice Hall: London.

3 ALBAUM, G. \& TSE, D. (2001) "Adaptation of international marketing strategy components, competitive advantage, and firm performance: A study of Hong Kong exporters“, Journal of International Marketing, 9(4): 59-81.

4 ARMSTRONG, J. \& OVERTON, T. (1977) "Estimating non-response bias in mail surveys", Journal of Marketing Research, 14(3): 396-402.

5 BALDAUF, A.; CRAVENS, D. \& WAGNER, U. (2000) "Examining determinants of export performance in small open economies", Journal of World Business, 35(1): 61-79.

6 CALOF, J. (1994) "The relationship between firm size and export behaviour revisited", Journal of International Business Studies, 25(2): 367-387.

7 CAVUSGIL, S. (1996) "Pricing for global markets", Columbia Journal of World Business, 31(4): 66-78.

8 CAVUSGIL, S. \& ZOU, S. (1994) "Market strategy-performance relationship: An investigation of the empirical link in export market ventures", Journal of Marketing, 58(1): 1-21.

9 CAVUSGIL, S.; ZOU, S. \& NAIDU, G. (1993) "Product and promotion adaptation in export ventures: An empirical investigation", Journal of International Business Studies, 24(3): 479-506.

10 CHEE, H \& HARRIS, R. (1998) Global Marketing Strategy, Pitman Publishing: London.

11 CHUNG, H. (2005) "An investigation of crossmarket standardisation strategies: Experiences in the European market", European Journal of Marketing, 39(11/12): 1345-1371.

12 CHURCHILL, G.A. (1979) "A paradigm for developing better measures of marketing constructs", Journal of Marketing Research, 16(1): 64-73.

13 CICIC, M.; PATTERSON, P. \& SHOHAM, A. (2002) "Antecedents of international performance: A service firms' perspective", European Journal of Marketing, 36(9): 1103-1118.

14 DAS, M. (1994) "Successful and unsuccessful exporters from developing countries", European Journal of Marketing, 28(12): 19-33.

15 DEAN, D.; MENGÜÇ, B. \& MYERS, C. (2000) "Revisiting firm characteristics, strategy, and export performance relationships: A survey of the literature and an investigation of New Zealand small manufacturing firms", Industrial Marketing Management, (29): 461-477.

16 ELINDER, E. (1965) "How international can European advertising be?" Journal of Marketing, 29(2): 7-11.

17 GRIFFITH, D. \& RYANS, J. (1995) "Strategically employing natural channels in an era of global marketing”, Journal of Marketing Practice: Applied Marketing Science, 1(4): 52-69.

18 HARRIS, G. (1996) "Factors influencing the international advertising practices of multinational companies”, Management Decision, 34(6): 5-11.

19 JULIAN, C. (2003) "Export marketing performance: A study of Thailand firms", Journal of Small Business Management, 41(2): 213-221.

20 KANSO, A. \& NELSON, R. (2002) "Advertising localization overshadows standardization", Journal of Advertising Research, 42(1): 79-89.

21 KATSIKEAS, C.; LEONIDOU, L. \& MORGAN, N. (2000) "Firm-level export performance assessment: Review, evaluation, and development", Journal of the Academy of Marketing Science, 28(4): 493-511.

22 LAGES, L. \& LAGES, C. (2004) "The STEP scale: A measure of short-term performance improvement", Journal of International Marketing Review, 12(1): 36-56.

23 LEONIDOU, L. (1996) "Product standardization or adaptation: The Japanese approach”, Journal of Marketing Practice Applied Marketing Science, 2(4): 53-71. 
24 MARSH, G. (2000) "International pricing - A market perspective", Marketing Intelligence and Planning, 18(4): 200-205.

25 MELEWAR, T. \& SAUNDERS, J. (1999)

"International corporate visual identity: Standardization or localization?" Journal of International Business Studies, 30(3): 583-598.

26 MORGAN, R. (1997) "Export stimuli and export barriers: Evidence from empirical research studies", European Business Review, 97(2): 68-79.

27 MORGAN, N.; KALEKA, A. \& KATSIKEAS, C. (2004) "Antecedents of export venture performance: A theoretical model and empirical assessment", Journal of Marketing, 68(1): 90-108.

28 MORGAN, R. \& KATSIKEAS, C. (1998) "Exporting problems of industrial manufacturers", Industrial Marketing Management, 27(2): 161-176.

29 O'CASS, A. \& JULIAN, C. (2003a) “Modelling the effects of firm-specific and environmental characteristics on export marketing performance", Journal of Global Marketing, 16(3): 53-74.

30 O'CASS, A. \& JULIAN, C. (2003b) "Examining firm and environmental influences on export marketing mix strategy and export performance of Australian exporters", European Journal of Marketing, 37(3/4): 366-384.

31 PALLANT, J. (2003) SPSS Survival Manual: A Step by Step Guide to Data Analysis Using SPSS for Windows (Versions 10 \& 11) Open University Press: Philadelphia.

32 PAPAVASSILIOU, N. \& STATHAKOPOULOS, V. (1997) "Standardization versus adaption of international advertising strategies towards a framework", European Journal of Marketing, 31(7): 504-527.

33 RANKIN, N. (2002) "The export behaviour of South African manufacturing firms", TIPS Working Paper 5: 1-23.

34 RAYMOND, M.; TANNER, J. \& KIM, J. (2001)

"Cost complexities of pricing decisions for exporters in developing and emerging markets", Journal of International Marketing, 9(3): 19-40.

35 RIALP, A.; AXINN, C. \& THACH, S. (2002) "Exploring channel internationalization among Spanish exporters", International Marketing Review, 19(2): 133-155.

36 RICHEY, G. \& MYERS, M. (2001) "An investigation of market information use in export channel decisions: Antecedents and outcomes",
International Journal of Physical Distribution and Logistics Management, 31(5): 334-353.

37 SAMIEE, S. \& ROTH, K. (1992) "The influence of global marketing standardization on performance", Journal of Marketing, 56(2): 1-17.

38 SAMLI, A. \& JACOBS, L. (1993/94) "International pricing decisions: A diagnostic approach", Journal of Marketing -Theory and Practice, 1(4): 29-41.

39 SCHUH, A. (2000) "Global standardization as a success formula for marketing in Central Eastern Europe?" Journal of World Business, 35(2): 133148.

40 SHOHAM, A. (1995) "Global marketing standardization”, Journal of Global Marketing, 9(1/2): 91-119.

41 SHOHAM, A. (1998) "Export performance: A conceptualization and empirical assessment", Journal of International Marketing, 6(3): 59-81.

42 SHOHAM, A. (1999) "Bounded rationality, planning, standardisation of international strategy and export marketing performance: A Structural Model”, Journal of International Marketing, 7(2): 24-50.

43 SHOHAM, A. (2002) "Standardization of international strategy and export performance: A meta-analysis", Journal of Global Marketing, 16(1/2): 97-120.

44 SHOHAM, A. \& KROPP, F. (1998) "Explaining international performance: Marketing mix, planning and their interaction", Marketing Intelligence and Planning, 16(2): 114-123.

45 STYLES, C. (1998) "Export performance measures in Australia and the United Kingdom", Journal of International Marketing, 6(3): 12-36.

46 SUDMAN, S. \& BLAIR, E. (1998) Marketing Research: A Problem-solving Approach, Irwin McGraw-Hill: New York.

47 THIRKELL, P. \& DAU, R. (1998) "Export performance: Success determinants for New Zealand manufacturing exporters", European Journal of Marketing, 32(9/10): 813-829.

48 VANDERSLUIS, C. (1999) "Creating effective international marketing channels", Ivey Business Journal, 64(2): 13-15.

49 ZOU, S. \& STAN, S. (1998) “The determinants of export performance: A review of the empirical literature between 1987 and 1997”, International Marketing Review, 15(5): 333-356. 